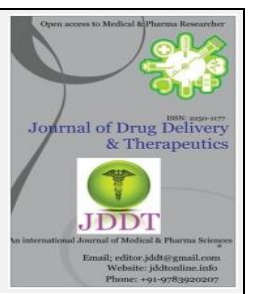

\title{
Evaluation of Antiulcerogenic Activity of Clerodendron Infortunatum Extract on Albino Rat Gastric Ulceration
}

\author{
*Kumar Arun1, Shukla Rahul 1, Chaudhary Anurag 2 \\ ${ }^{1}$ School of Pharmaceutical Sciences, Sri Venkateswara University, Gajraula, U.P.- 244236, India \\ 2 Department of Pharmaceutical Technology, Meerut Institute of Engineering \& Technology, Baghpat Bypass Crossing, N.H. 58, Delhi- \\ Haridwar Highway, Meerut-250005, India
}

\begin{abstract}
Clerodendron infortunatum Linn. (Verbenaceae) is an important and widely used medicinal plant, reported to contain active bitter substance like clerodin, has been widely used as tonic and anthelmintic agent in the country sides of North India. Though, variously used in Ayurved a, Unani system of medicine and Homeopathy in case of ailments like diarrhoea, skin disorders, venereal and scrofulous complaints, wounds, post-natal complications, as vermifuge, laxative and cholagogue, for the removal of ascarids in anus, as external applications on tumours, etc.,

Background: The present study reports the antiulcer properties of 50\% ethanolic extract of Clerodendron infortunatum Linn. (Verbenaceae) leaves have assessed in different acute and chronic gastric ulcer models in rats.

Methods: EECI (100, 200 and $400 \mathrm{mg} / \mathrm{kg}$ body weight) was administered orally, twice daily for 5 days for prevention from ethanol (EtOH), Cold-restraint stress (CRS), Pylorus-ligation (PL) and 10 days for prevention of acetic acid induced ulcers.

Results: The EECI showed significant gastric ulcer protective effect in doses of $400 \mathrm{mg} / \mathrm{kg}$, when given twice daily for 5 days against gastric ulcers induced by ethanol (EtOH), cold restraint stress (CRS) and pyloric ligation (PL). EECI showed dose dependent decrease in ulcer index (UI) against ulcers induced by: (i) Ethanol (control UI: 29.52 $\pm 2.4 \mathrm{~mm} 2 / \mathrm{rat}$, EECI decrease $21.12 \pm 2.3$ - $5.3 \pm 1.0$ (ii) Cold restraint stress (CRS) (control UI: $32.13 \pm 2.1$, EECI decrease $24.02 \pm 2.2$ - 4.7 \pm 1.1 (iii) pylorus ligation (control UI: $29.25 \pm 2.4 \mathrm{~mm} 2 /$ rat, EECI decrease $22.32 \pm 2.7-$ $5.3 \pm 1.0$, EECI $400 \mathrm{mg} / \mathrm{kg}$ significantly healed ulcers induced by $50 \%$ acetic acid after 5 (control UI: $32.30 \pm 2.9$, EECI decrease $26.27 \pm 1.9-$ $8.56 \pm 0.98$ and after 10 days treatment (control UI: $29.02 \pm 2.6$, healing 21.28 $\pm 2.1-5.78 \pm 1.2$. EECI prevents the oxidative damage of gastric mucosa by blocking lipid peroxidation and by significant decrease in superoxide dismutase, and increase in catalase activity.
\end{abstract}

Conclusions: Our results show that Clerodendron infortunatum Linn. (Verbenaceae) possess significant gastro-protective activity which might be due to gastric defence factors and clerodin might be the main constituents responsible for this activity.

Keywords: Clerodendron infortunatum L; Anti-ulcer; Antioxidant; Gastroprotective; Lipid peroxidation (LPO); Superoxide dismutase (SOD)

Article Info: Received 08 July 2019; $\quad$ Review Completed 13 August 2019; Accepted 17 August 2019; Available online 30 Aug 2019

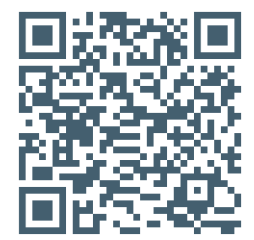

\section{Cite this article as:}

Kumar A, Shukla R, Chaudhary A, Evaluation of Antiulcerogenic Activity of Clerodendron Infortunatum Extract on Albino Rat Gastric Ulceration, Journal of Drug Delivery and Therapeutics. 2019; 9(4-A):57-62

http://dx.doi.org/10.22270/jddt.v9i4-A.3337

Kumar Arun, School of Pharmaceutical Sciences, Sri Venkateswara University, Gajraula, U.P.- 244236.

\section{INTRODUCTION}

Over the past decade, herbal and ayurvedic drugs have become a subject of world importance, with both medicinal and economic implications. A regular and widespread use of herbs throughout the world has increased serious concerns over their quality, safety and efficacy. Clerodendrum infortunatum Linn. (Verbanaceae) Bhat in Hindi (terrestrial shrub) is common throughout the plains of India (Kirtikar \& Basu 1996), (Nadkarni \& Nadkarni, 2000) found along roadsides in North India and elsewhere, and, flowering during February-May (Haines, 1925). Clerodendrum infortunatum leaves on preliminary chemical analysis are found to contain saponin, clerodin (a bitter diterpene) and some enzymes. Leaves also contain a fixed oil which consists of glycerides of lenoleic, oleic, stearic and lignoceric acid (Sai et al., 2002). Clerodendron infortunatum is an important and widely used medicinal plant, reported to contain active bitter substance like clerodin, has been widely used in Ayurveda, Unani system of medicine and Homeopathy. Leaves and roots are used for external applications on tumours are due to the presence of clerodolone, clerodone, clerodol and a sterol now designated as clerosterol (Rajurkar et at 2010). Clerodin 
(C13H1803) is supposed to be the main active compound that may interact with some target molecules of the human system (Barton et. al., 1961). Significant wound healing was observed in animals treated with chloroform and ethanol extracts, similar to the reference standard drug nitrofurazone. The presence of bioactive constituents such as polyphenols, flavonoids are thought to promote the wound-healing process due to their antioxidant and antimicrobial activities (Gouthamchandra et al., 2009 \& Sannigrahi et al., 2009).

Hence the present study was planned to evaluate antiulcer activity and antioxidant activity of alcoholic extracts of leaves of Clerodendrum infortunatum Linn. in ulcer model in experimental animals. So the study is essential and justifiable.

\section{METHODS}

\section{Plant material Collection and Extraction}

Fresh leaves of $C$. infortunatum were collected from the field, washed and shade dried. These dried leaves were ground into fine powder with an electric mixer grinder and 200 gms of leaf powder was extracted using $1000 \mathrm{ml}$ ethanol. The extract was filtered and the filtrate was dried under vacuum on a water bath at $50^{\circ} \mathrm{c}$ to provide EECI extract.

\section{Test animals}

Sprague-Dawley rats $(140-180 \mathrm{~g})$ were procured from the animal house of Central Drug Research Institute, Lucknow. They were kept in the departmental animal house at $26 \pm 2$ ${ }^{\circ} \mathrm{C}$ and relative humidity $44-56 \%$, light and dark cycles of 10 and $14 \mathrm{hrs}$, respectively for 1 week before and during the experiments. Animals were provided with standard rodent pellet diet (Amrut, India) and the food was withdrawn 18$24 \mathrm{hrs}$ before the experiment though water was allowed ad libitum. All experiments were performed in the morning according to current guidelines for the care of laboratory animals and the ethical guidelines for investigations of experimental pain in conscious animals.

\section{Phytochemical screening}

The leaves of Clerodendrum infortunatum Linn. was reported to contain saponin, alkyl sterols, some enzymes (Khatri 2005), and 2,-(3, 4-dehydroxyphenyl) ethanol1-0- $\alpha-$

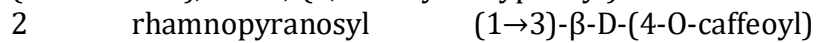
glycolpyranoside (acetoside) (Khatri 2005 \& Prajapati et al., 2001). It was also found that the leaves contain a fixed oil which consists of glycerides of lenoleic, oleic, stearic and lignoceric acid (Kapoor 2001). Abbaszadeh et al reported isolation of three compounds identified as clerodin, 15methoxy-14, 15-dihydroclerodin and 15-hydroxy-14, 15dihydroclerodin from this plant. besides the above major chemicals found in the clerodendrum genus the other constituents are carbohydrates, phenolic, flavonoids, terpenoids, sugars and steroids (Sharma et al., 2008). Various parts of $C$. infortunatum contain quercetin, having the highest concentration in the flowers, followed by leaves and then roots (Gupta et al., 2012).

\section{Toxicity studies}

The acute toxicity of EECI in male Swiss albino mice was studied as reported method (Litchfield and Welcoxon 1949). EECI was given to four groups $(n=6)$ of animals at 50, 500, 1500 and $2000 \mathrm{mg} / \mathrm{kg}$ body weight, i.p. The treated animals were kept under observation for 3 days, for mortality and general behavior. No death was observed till the end of the study. It was observed that the rats were not mortal even at $2000 \mathrm{mg} \mathrm{kg}-1$ dose of EECI. Hence, 1/5th
(400 mg/kg), 1/10th (200 mg/kg) and $1 / 20^{\text {th }}(100 \mathrm{mg} / \mathrm{kg})$ of EECI were selected as high dose, standard and low dose, respectively for this study.

\section{Experimental procedure}

EECI, suspended in 1\% carboxy methyl cellulose (CMC) in distilled water in doses of 100,200 and $400 \mathrm{mg} / \mathrm{kg}$ and Omeprazole, the reference drug, in the dose of $50 \mathrm{mg} / \mathrm{kg}$ were administered orally twice daily at 10:00 and 16:00 h, respectively, for 5 days for ulcer protective studies. Further the effective dose of EECI $100 \mathrm{mg} / \mathrm{kg}$, b.d for 5 days was used for secretion and mucosal studies, and up to 10 days for ulcer healing study. Control group of animals received suspension of $1 \% \mathrm{CMC}$ in distilled water.

\section{Anti-ulcer study}

The following experimental models were used.

\section{Ethanol (EtOH)-induced ulcers}

The gastric ulcers were induced in rats by administering EtOH (1 ml/200 g, $1 \mathrm{~h}$ ) (Hollander et al., 1984) and the animals were sacrificed by cervical dislocation and stomach was incised along the greater curvature and examined for ulcers. The ulcer index was scored by a person unaware of the experimental protocol, based upon the product of length and width of the ulcers present in the glandular portion of the stomach ( $\mathrm{mm} 2 /$ rat). Statistical analysis of data was done by using unpaired Student's $t$-test.

\section{Cold-restraint stress (CRS)-induced ulcers}

On day 6 to $18 \mathrm{~h}$ fasted rats, cold restraint stress was given by strapping the rats on a wooden plank and keeping them for $2 \mathrm{~h}$ at $4-6^{\circ} \mathrm{C}$. The animals were then sacrificed by cervical dislocation and ulcers were scored on the dissected stomachs (Gupta et al., 1985) as described above.

\section{Acetic acid-induced ulcers}

The rats were anaesthetized with pentobarbitone (35 $\mathrm{mg} / \mathrm{kg}$, i.p.). The abdomen was opened and the stomach was visualized. A cylindrical glass tube of $6 \mathrm{~mm}$ in diameter was tightly placed upon the anterior serosal surface of the glandular portion of stomach $1 \mathrm{~cm}$ away from the pyloric end. A total of $50 \%$ acetic acid $(0.06 \mathrm{ml} /$ animal) was instilled into the tube and allowed to remain $60 \mathrm{~s}$ on the gastric wall. After removal of the acid solution, the abdomen was closed in two layers and animals were caged and fed normally. EECI was given in the dose of $200 \mathrm{mg} / \mathrm{kg}$ on day 1 , orally, twice daily, $4 \mathrm{~h}$ after the application of acetic acid and continued either up to 5 or 10 days after induction of the ulcer. The animals were then sacrificed after $18 \mathrm{~h}$ of the last dose of drug either on day 6 or day 11 of experiment to assess the ulcer size and healing. Ulcer index was calculated based upon the product of length and width (mm2/rat) of ulcers (Goel and Maiti, 1992). Statistical significance was calculated using unpaired Student's t -test.

\section{Pylorus-ligation (PL)-induced ulcers}

Drugs were administered for a period of 5 days as described above. On day 6 after the last dose, the rats were kept for 18 $\mathrm{h}$ fasting and care was taken to avoid coprophagy. Animals were anaesthetized using pentobarbitone (35 mg/kg, i.p.), the abdomen was opened and pylorus ligation was done without causing any damage to its blood supply. The stomach was replaced carefully and the abdomen wall was closed in two layers with interrupted sutures. The animals were deprived of water during the post-operative period (Sanyal et al., 1971). After $4 \mathrm{~h}$, stomachs were dissected out and contents were collected into tubes for estimation of 
biochemical parameters. The ulcers were scored as described in acetic acid induced ulcers.

\section{Determination of gastric wall mucus}

Gastric wall mucus was determined according to the method of (Corne et al., 1974). The glandular segments from stomachs were removed, weighed and incubated in tubes containing $1 \%$ Alcian blue solution $(0.16 \mathrm{M}$ sucrose in $0.05 \mathrm{M}$ sodium acetate, $\mathrm{pH} 5.8$ ) for $2 \mathrm{~h}$. The alcian blue binding extract was centrifuged at $3000 \mathrm{rpm}$ for $10 \mathrm{~min}$ and the absorbency of supernatant was measured at $498 \mathrm{~nm}$. The quantity of alcian blue extracted (gm per gm of glandular tissue) was then calculated.

\section{Gastric secretion study}

The gastric juice was collected $4 \mathrm{~h}$ after PL and centrifuged for $5 \mathrm{~min}$ at $2000 \mathrm{rpm}$. The volume of the supernatant is expressed as $\mathrm{ml} / 100 \mathrm{~g}$ body weight while total acid output was determined by titrating with $0.01 \mathrm{~N} \mathrm{NaOH}$, using phenolphthalein as indicator and is expressed either as $\mu \mathrm{Eq} / \mathrm{ml}$ for concentration or $\mu \mathrm{Eq} / 4 \mathrm{~h}$ for output. Peptic activity was estimated following the method of (Debnath et al., 1974) and expressed either as $\mu \mathrm{mol}$ of tyrosine $/ \mathrm{ml}$ for concentration or $\mu \mathrm{mol}$ of tyrosine $/ 4 \mathrm{~h}$ for output. Dissolved muco-substances were estimated in the $90 \%$ alcoholic precipitate precipitate of the gastric juice. Protein (Lowry et al., 1951), total hexoses, hexosamine, sialic acid and fucose, the constituents of the above dissolved muco-substances, were estimated (Sanyal et al., 1983). The results are expressed in $\mu \mathrm{g} / \mathrm{ml}$. The ratio of total carbohydrates (TC, sum of total hexoses, hexosamine, fucose and sialic acid) to protein $(\mathrm{P})$ has been taken as the index of mucin activity (Sanyal et al., 1983). DNA content was estimated and expressed as $\mu \mathrm{g} / \mathrm{ml}$ gastric juice $100 \mathrm{~g}$ weight of rats (Mukhopadhyay et al., 1987).

\section{Estimation of mucosal glycoproteins}

Samples of gastric mucosal scraping were homogenized in distilled water and treated with $90 \%$ ethanol and were subjected for the estimation of carbohydrates and proteins using the methods described above for gastric juice contents (Goel et al.,1994). Statistical analysis of data was done by using unpaired Student's $t$-test.

\section{Cell proliferation}

\section{Estimation of DNA in gastric mucosa}

Mucosal scraping was homogenized in $2.5 \mathrm{ml}$ of ice cooled $0.6 \mathrm{~N}$ perchloric acid (PCA). DNA (Goel et al., 1986) and protein (Lowry et al., 1951), were then estimated. The concentration of DNA is expressed as $\mu \mathrm{g}$ DNA/mg protein.

\section{Estimation of free radical generation}

EECI in the dose of $200 \mathrm{mg} / \mathrm{kg}$ was given orally, daily for 5 days and on day 6 of experiment, $1 \mathrm{~h}$ prior to subjecting the animals to CRS, the animals were then sacrificed and the ulcer index was calculated as described earlier. The fundic part of the stomach was homogenized (5\%) in ice cold $0.9 \%$ saline with a Potter-Elvehjem glass homogenizer for $30 \mathrm{~s}$. The homogenate was then centrifuged at $800 \times \mathrm{g}$ for $10 \mathrm{~min}$ followed by centrifugation of the supernatant at $12,000 \times \mathrm{g}$ for $15 \mathrm{~min}$ and the obtained mitochondrial fraction was used for the following estimations (Das and Banerjee 1993), (Goel et al., 2001).

\section{Lipid peroxidase (LPO) activity}

LPO product malondialdehyde (MDA) was estimated using 1,1,3,3-tetraethoxypropane as the standard and is expressed as nmol/mg protein (Okhawa et al., 1979).

\section{Superoxide dismutase (SOD) activity}

SOD was estimated by following the procedure of (Kakkar and Das, 1984). The inhibition of reduction of nitro blue tetrazolium (NBT) to blue colored formozanin presence of phenazine metha sulphate (PMS) and NADH was measured at $560 \mathrm{~nm}$ using n-butanol as blank. One unit (U) of enzyme activity was defined as the amount of enzyme that inhibits rate of reaction by $50 \%$ in 1 min under the defined assay conditions and the results have

\section{Catalase (CAT) activity}

Decomposition of $\mathrm{H} 2 \mathrm{O} 2$ in presence of catalase was followed at $240 \mathrm{~nm}$ (Beer and Sizer, 1952). One unit of (U) CAT was defined as the amount of enzyme required to decompose $1 \mathrm{mmol}$ of $\mathrm{H}_{2} \mathrm{O}_{2} / \mathrm{min}$, at $25^{\circ} \mathrm{C}$ and $\mathrm{pH}$ 7.0. Results are expressed as U of CAT activity/mg protein. Statistical analysis was done by Student's t -test.

\section{Statistical analysis}

Values were represented as mean \pm S.E.M. for six rats. Analysis of variance (ANOVA) test was followed by individual comparison by Newmann Keuls test for the determination of level of significance.

\section{RESULT}

\section{Antiulcer and ulcer healing effects}

The ethanolic extract of $C$. infortunatum (EECI) showed significant gastric ulcer protective effect in doses of 100 $400 \mathrm{mg} / \mathrm{kg}$, when given twice daily for 5 days against gastric ulcers induced by ethanol (EtOH), cold restraint stress (CRS) and pyloric ligation (PL). EECI showed dose dependent decrease in ulcer index (UI) against ulcers induced by: (i) Ethanol (control UI: 29.52 $\pm 2.4 \mathrm{~mm} 2 / \mathrm{rat}$, EECI\% decrease $28.45-82.04 \%$, PB 0.05 to PB 0.001); (ii) Cold restraint stress (control UI: $32.13 \pm 2.1$, EECI\% decrease 25.30 - 85.06\%, PB 0.2 to PB 0.001); and (iii) Pylorus ligation (control UI: 29.25 \pm 2.4 , EECI\% decrease 22.32 $80.85 \%$, PB 0.1 to PB 0.001 ) (Table 1). A total of $50 \%$ acetic acid when applied to the serosal surface of rat gastric mucosa in the fundal region near to the pyloric end produced chronic gastric ulcers. EECI $400 \mathrm{mg} / \mathrm{kg}$ significantly healed ulcers induced by $50 \%$ acetic acid after 5 (control UI: $32.30 \pm 2.9$, healing $18.67-73.49 \%$, PB/0.001) and (control UI: $29.02 \pm 2.6$, healing $26.67-80.08 \%, \mathrm{~PB} / 0.01$ ) after 10 days of treatment (Table 2).

\section{Effect on acid-pepsin secretion}

The effect of EECI on various parameters of offensive factors was studied the volume, acid and pepsin secretion in the gastric juice of $4 \mathrm{~h}$ PL rats. The mean \pm S.E.M. values of control group were: volume $1.93 \pm 0.02 \mathrm{ml} / 100$ g body weight; acid concentration $139.2 \pm 1.7 \mu \mathrm{Eq} / \mathrm{ml}$ and output $244.5 \pm 2.5 \mu \mathrm{Eq} / 4 \mathrm{~h}$; pepsin concentration $448.5 \pm 4.3 \mu \mathrm{mol}$ of tyrosine $/ \mathrm{ml}$ and output $833.8 \pm 2.8 \mu \mathrm{mol}$ of tyrosine $/ 4 \mathrm{~h}$ respectively. EECI $400 \mathrm{mg} / \mathrm{kg}$ decreased the volume (decrease 8.29\%, PB 0.05), acid concentration (decrease $23.71 \%$, PB 0.01), output (decrease 19.55\%, PB 0.01), pepsin concentration $(21.69 \%$, PB 0.4$)$, output $(50.50 \%$, PB 0.001) while Omeprazole caused inhibition of the above parameters to $10.36 \%, 24.42 \%, 24.33 \%, 22.14 \%$ and $50.31 \%$ (PB 0.001) respectively (Table.3).

\section{Effect on cell shedding and proliferation}

Increase or decrease in life span of mucosal cells can be expressed as the amount of DNA present in the gastric juice after test drug treatment the mean \pm S.E.M. value of control DNA content of gastric juice was: $234.2 \pm 1.87 \mu \mathrm{g} / \mathrm{ml}$ per 100 $\mathrm{g}$ body weight and was decreased significantly both by EECI 
and Omeprazole pretreatment indicating enhancement of life span of mucosal cells (EECI $170.2 \pm 2.52 \mu \mathrm{g} / \mathrm{ml} 27.32 \%$ inhibition, PB 0.05; Omeprazole 168.7 $\pm 0.72 \mu \mathrm{g} / \mathrm{ml} \mathrm{27.96 \%}$ inhibition, PB 0.05) (Table.3). For cell proliferation study, the effect of EECI $400 \mathrm{mg} / \mathrm{kg}$ was seen both on the weight of the glandular portion of rat stomach and $\mu \mathrm{g}$ DNA/mg protein which are indicative of any cell proliferation. EECI showed little or no change in all the above parameters.

\section{Effect on mucin secretion and mucosal glycoproteins}

Both EECI $400 \mathrm{mg} / \mathrm{kg}$ and Omeprazole $50 \mathrm{mg} / \mathrm{kg}$ either tended to increase or increased the concentration of individual carbohydrates and total carbohydrates (TC) in the alcoholic precipitate of gastric juice with significant decrease in protein (P) content leading to significant increase in TC:P ratio, a marker of mucin secretion (Table 4). Both EECI and Omeprazole showed again similar effect on mucosal glycoproteins content of the mucosa as observed by an increase in TC: P ratio.

\section{Antioxidant effect}

When the animals were treated with EECI $400 \mathrm{mg} / \mathrm{kg}$ was significant reduced the LPO, SOD and CAT level by $0.45 \pm 0.01,98 \pm 3.3 \& 24 \pm 2.0(\mathrm{P}<0.001) \&(\mathrm{P}<0.001)$ as compared to elevated level in CRS $0.51 \pm 0.02,114 \pm 3.7$ \& $35 \pm 2.4(\mathrm{P}<0.001)$. LPO, SOD and CAT levels near to the normal values when compared to the stress group (UI $4.8 \pm 0.8, \mathrm{~PB} / 0.001), \mathrm{P}<0.001)$. EECI was significant reversal in the ulcer index, LPO, SOD and CAT levels near to the normal values when compared to the stress group (Fig. 1).

EECI showed significant ulcer protective and healing effects as observed from significant decrease in acute ulcers induced by ethanol, aspirin, cold restraint stress and pyloric ligation and healing of chronic ulcers induced by acetic acid. Gastric ulcer is often a chronic disease and it may persist for 10-20 years characterized by repeated episodes of healing and re-exacerbations. The incidence of ethanol-induced ulcers is predominant in the glandular part of stomach was reported to stimulate the formation of leukotriene C4 (LTC4), mast cell secretory products (Oates and Hakkinen 1988) and reactive oxygen species (Mizui et al.,1987) resulting in the damage of rat gastric mucosa (Peskar et al., 1986). Ethanol-induced depletion of gastric wall mucus has been prevented by EECI. Ethanol is metabolised in the body and releases superoxide anion and hydro-peroxy free radicals. Ulcers caused by ethanol are due to superficial damage to mucosal cells (Miller and Henagan 1984) and damage by NSAIDs are due to decrease in PG synthesis and increase in acid secretion (Goel and Bhattacharya 1991).

Pylorus ligation-induced ulcers are due to auto-digestion of the gastric mucosa and break down of the gastric mucosal barrier (Sairam et al., 2002). Its reported adaptogenic (Rege et al., 1999) and antimicrobial (Ahmad et al., 1998) effects may as well account for part of its anti-ulcerogenic activity. EECI significantly decreased the acid and pepsin secretion. Mucus serves as first line of defense against ulcerogens. Mucus is secreted by the mucus neck cells and covers the gastric mucosa thereby preventing physical damage and back diffusion of hydrogen ions (Williams and Turnberg 1980). Hence increase in synthesis of mucus may be one of the important contributing factors for ulcer protective role of EECI.

The decrease in DNA content of gastric mucosa indicates decreased cell shedding and increased life span of cells (Mukhopadhyay et al., 1987). Increase in glycoprotein content of gastric mucosa is evidenced from increase in TC: $P$ ratio of the mucosal cells, which is taken as marker for cellular mucus (Goel et al., 1994). This increase was due to increase in muco-polysaccharides, the major constituent of mucus and also which are responsible for viscous nature and gel-forming properties of the mucus.

Ulcers due to stress are both due to physiological and psychological factors (Miller et al., 1987) and those by pyloric ligation are due to increased accumulation of gastric acid and pepsin leading to auto digestion of gastric mucosa (Goel and Bhattacharya 1991). Chronic ulcers by acetic acid are due to increase in volume of acid output leading to subsequent pyloric obstruction and mucosal necrosis (Okabe and Pfeiffer 1980). Stress plays an important role in etiopathology of gastro-duodenal ulceration. Increase in gastric motility, vagal over activity (Cho et al., 1976) mast cell degranulation (Cho and Ogle 1979) decreased gastric mucosal blood flow (Hase and Moss 1973) and decreased prostaglandin synthesis (Rao et al., 1999) are involved in genesis of stress induced ulcers. Acetic acid-induced ulcer better resembles clinical ulcers in location, chronicity and severity and servers as the most reliable model to study healing process (Okabe and Pfeiffer 1980). EECI significantly healed the penetrating ulcers induced by acetic acid after 5 and 10 days treatment.

The role of free radicals in gastric ulcerations is well documented (Cochran et al., 1983). EECI significantly reduced lipid peroxidation in rat gastric mucosa. SOD scavenges the super oxide radical $\mathrm{O}_{2}{ }^{-}$, one of the reactive oxygen species (ROS) responsible for lipid peroxidation (Fridovich 1986). This reaction leads to increase in generation of peroxyl radical $\mathrm{H}_{2} \mathrm{O}_{2}-$, which is also capable of producing more oxidative damage (Das et al., 1997). CAT and other peroxidases further reduce $\mathrm{H}_{2} \mathrm{O}_{2}{ }^{-}$. Hence, the anti-oxidant activity in gastric mucosal homogenates observed from decrease in LPO may be due to increase in SOD and CAT levels. During stress LPO and SOD were significantly increased and CAT level was significantly decreased. The increase in SOD was due to increased ROS generation during mucosal damage. 
Table 1. Effect of ethanolic extract of leaves of Clerodendrum infortunatum (L.) (EECI $\mathrm{mg} / \mathrm{kg}$, twice daily for 5 days) on ethanol (EtOH, 100\%, 1 ml/200 g, p.o., 1 h), pylorus ligation (PL) and cold restraint stress (CRS) induced gastric ulcers in rats

\begin{tabular}{|l|c|c|c|c|c|c|}
\hline \multirow{2}{*}{ Treatment } & \multicolumn{2}{|l|}{ Ethanol Induced model } & \multicolumn{2}{l|}{ CRS model } & \multicolumn{2}{l|}{ Pyloric ligation (PL) } \\
\cline { 2 - 8 } & $\begin{array}{l}\text { Ulcer index } \\
\left(\mathrm{mm}^{2} / \mathrm{rat}\right)\end{array}$ & $\begin{array}{l}\text { Percent } \\
\text { protection }\end{array}$ & $\begin{array}{l}\text { Ulcer index } \\
\left(\mathrm{mm}^{2} / \mathrm{rat}\right)\end{array}$ & $\begin{array}{l}\text { Percent } \\
\text { protection }\end{array}$ & $\begin{array}{l}\text { Ulcer index } \\
\left(\mathrm{mm}^{2} / \mathrm{rat}\right.\end{array}$ & $\begin{array}{l}\text { Percent } \\
\text { protection }\end{array}$ \\
\hline Ethanol & $29.52 \pm 2.4$ & -- & $32.13 \pm 2.1$ & -- & $29.25 \pm 2.4$ & -- \\
\hline $\begin{array}{l}\text { C. infortunatum Linn. } \\
\text { Extract 100(mg/kg) }\end{array}$ & $21.12 \pm 2.3$ & $28.45 \%$ & $24.02 \pm 2.2$ & $25.30 \%$ & $22.32 \pm 2.7$ & $23.69 \%$ \\
\hline $\begin{array}{l}\text { C. infortunatum Linn. } \\
\text { Extract 200(mg/kg) }\end{array}$ & $15.12 \pm 1.7$ & $48.78 \%$ & $14.17 \pm 1.9 \mathrm{a}$ & $55.89 \%$ & $13.08 \pm 1.6$ & $55.28 \%$ \\
\hline $\begin{array}{l}\text { C. infortunatum Linn. } \\
\text { Extract 400(mg/kg) }\end{array}$ & $5.3 \pm 1.0 \mathrm{a}$ & $82.04 \%$ & $4.7 \pm 1.1 \mathrm{~b}$ & $85.37 \%$ & $5.3 \pm 1.0$ & $81.88 \%$ \\
\hline Omeprazole 50(mg/kg) & $6.4 \pm 0.4 \mathrm{a}$ & $78.32 \%$ & $4.8 \pm 0.8 \mathrm{~b}$ & $85.06 \%$ & $5.6 \pm 0.91$ & $80.85 \%$ \\
\hline
\end{tabular}

$\mathrm{aP}<0.05 ; \mathrm{bP}<0.001$ as compared to their respective control. Data are Mean \pm S.E.M., $\mathrm{n}=6$ in each group.

Table 2 - Effect of $C$. infortunatum (L.) leaves extract (twice daily for five days) on acetic acid-induced gastric ulcer.

\begin{tabular}{|l|c|c|c|c|}
\hline $\begin{array}{l}\text { Treatment and Dose } \\
\text { (mg/kg) }\end{array}$ & $\begin{array}{l}\mathbf{5} \text { days treated } \\
\text { Ulcer index }\end{array}$ & $\begin{array}{l}\text { \% incident of } \\
\text { perforation }\end{array}$ & $\begin{array}{l}\mathbf{1 0} \text { days treated } \\
\text { Ulcer index }\end{array}$ & $\begin{array}{l}\text { incident } \\
\text { perforation }\end{array}$ \\
\hline Control & $32.30 \pm 2.9$ & --- & $29.02 \pm 2.6$ & -- \\
\hline $\begin{array}{l}\text { C. infortunatum Linn. } \\
\text { Extract 100(mg/kg) }\end{array}$ & $26.27 \pm 1.9$ & $18.67 \%$ & $21.28 \pm 2.1$ & $26.67 \%$ \\
\hline $\begin{array}{l}\text { C. infortunatum Linn. } \\
\text { Extract 200(mg/kg) }\end{array}$ & $17.95 \pm 2.6^{\mathrm{b}}$ & $44.43 \%$ & $14.82 \pm 1.3^{\mathrm{b}}$ & $48.93 \%$ \\
\hline $\begin{array}{l}\text { C. infortunatum Linn. } \\
\text { Extract 400(mg/kg) }\end{array}$ & $8.56 \pm 0.98^{\mathrm{a}}$ & $73.49 \%$ & $5.78 \pm 1.2^{\mathrm{a}}$ & $80.08 \%$ \\
\hline Omeprazole 50 & $9.23 \pm 1.2^{\mathrm{a}}$ & $71.42 \%$ & $6.82 \pm 0.84^{\mathrm{a}}$ & $76.49 \%$ \\
\hline
\end{tabular}

aP< 0.001; bP $<0.01 \quad$ Values are mean \pm SEM for 6 rats.

Table 3. Effect of ethanolic extract of leaves of $C$. infortunatum (L.) (twice daily for 5 days) on gastric secretion in $4 \mathrm{~h}$ PL rats.

\begin{tabular}{|c|c|c|c|c|c|c|}
\hline \multirow{2}{*}{ Treatment } & \multirow{2}{*}{$\begin{array}{c}\text { Volume } \\
(\mathrm{ml} / 100 \mathrm{~g})\end{array}$} & \multicolumn{2}{|c|}{ Acid } & \multicolumn{2}{c|}{ Pepsin } & \multirow{2}{*}{ DNA } \\
\cline { 3 - 7 } & & Conc. & Output & Conc. & Output & $(\mu \mathrm{g} / \mathrm{ml})$ \\
\hline Control & $1.93 \pm 0.02$ & $139.2 \pm 1.7$ & $244.5 \pm 2.5$ & $448.5 \pm 4.3$ & $833.8 \pm 2.8$ & $234.2 \pm 1.87$ \\
\hline $\begin{array}{c}\text { C. } \text { infortunatum Linn. } \\
\text { Extract 100(mg/kg) }\end{array}$ & $1.83 \pm 0.03$ & $125.8 \pm 2.0$ & $229.2 \pm 2.1$ & $400.8 \pm 4.2$ & $796.2 \pm 4.2$ & $210.5 \pm 2.73$ \\
\hline $\begin{array}{c}\text { C. } \text { infortunatum Linn. } \\
\text { Extract 200(mg/kg) }\end{array}$ & $1.79 \pm 0.03$ & $110.5 \pm 0.8$ & $211.5 \pm 2.4$ & $382.3 \pm 3.3$ & $684.3 \pm 4.3$ & $201.7 \pm 2.33$ \\
\hline $\begin{array}{c}\text { C. } \text { infortunatum Linn. } \\
\text { Extract 400(mg/kg) }\end{array}$ & $1.77 \pm 0.02$ & $106.2 \pm 0.50$ & $196.7 \pm 3.1$ & $351.2 \pm 2.8$ & $412.7 \pm 2.4$ & $170.2 \pm 2.52 \mathrm{y}$ \\
\hline Omeprazole $50 \mathrm{mg} / \mathrm{kg}$ & $1.73 \pm 0.02$ & $105.2 \pm 1.1$ & $185 \pm 1.63$ & $349.3 \pm 2.9$ & $414.3 \pm 3.4 \mathrm{~m}$ & $168.7 \pm 0.72 \mathrm{~m}$ \\
\hline
\end{tabular}

aP $<0.001$; bP $<0.05 \quad$ Values are mean \pm S.E.M. $n=6$ ) in each group.

Table 4. . Effect of leaves of $C$. infortunatum (L.) (EECI) (twice daily for five days ) on lipid peroxidation (LPO), superoxide dismutase (SOD), and catalase (CAT) in CRS-induced gastric ulcer.

(data are mean \pm SEM, $n=6$ in each group)

\begin{tabular}{|l|l|l|l|l|}
\hline Treatment & Dose $(\mathrm{mg} / \mathrm{kg})$ & LPO & SOD & CAT \\
\hline Control & - & $0.51 \pm 0.02$ & $114 \pm 3.7$ & $35 \pm 2.4$ \\
\hline Sesamum indicum Linn. Extract & 100 & $0.64 \pm 0.01$ & $123 \pm 4.8$ & $27 \pm 3.6$ \\
\hline Sesamum indicum Linn. extract & 200 & $0.57 \pm 0.01$ & $112 \pm 4.6$ & $26 \pm 0.8$ \\
\hline Sesamum indicum Linn. Extract & 400 & $0.45 \pm 0.01$ & $98 \pm 3.3$ & $24 \pm 2.0$ \\
\hline
\end{tabular}

Values are mean \pm SEM for 6 rats.

$\mathrm{xP}<0.001$ compared to respective control group.

yP $<0.001$ compared to respective control group.

\section{REFERENCES}

1. Kirtikar KR. \& Basu BD: Indian Medicinal Plants, edited by K S Mhaskar \& J F Cains Sri Satguru Publications, Delhi, 1996; third edition, Vol. III, 2674.

2. Nadkarni KM \& Nadkarni AK: Indian Materia Medica Popular Publications, Mumbai, third edition, 2000; Vol. I, 353.

3. Haines, H.H. 1925 The Botany of Bihar and Orissa. Vol. II. Bishen Singh and Mahendra Pal Singh, Dehradun, India.
4. Barton, D.H.R., Cheung, H.T., Cross, A.D., Jackman, L.M. and M. Martin-Smith, M. 1961 Diterpenoid bitter principles. Part III. The constitution of clerodin. J. Chem. Soc5061 - 5073, DOI: 10.1039/JR9610005061.

5. Sai Prakash CV, Hoch JM \& Kingston DGI, Structure \& Stereochemistry of new cytotoxic Clerodan diterpenoids from 
the bark of Casearia lucida from the madagaskar rainforest, J Natural Products, 2002; 65(2) 100.

6. Rajurkar B. M. Morphological study and medicinal importance of clerodendrum infortunatum gaertn. (verbenaceae), found in tadoba national park, india, JPRHC, 2010; vol 2 (2) 216-220.

7. Gouthamchandra K, Riaz $M$, Basheer $M$, Khadeer $A$, Parameshwarappa SB, Venkatarangaiah K. Wound healing activity of Clerodendrum infortunatum Linn root extracts. Int J Biomed Pharm Sci 2009;3(1):21-5.

8. Sannigrahi S, Mazumder UK, Pal D, Parida S. In vitro anti oxidant activity of methanolic extract of Clerodendrum infortunatum Linn. OPEM 2009;9(2):128-34.

9. Prajapati ND, Purohit SS, Sharma AK, Kumar TA. A Handbook of Medicinal Plants. 1st ed. New Delhi: CRC Press; 2001. p. 154.

10. Khatri N. Studies on antinociceptive, anti-inflammatory and diuretic activity of methanolic extract of the aerial part of Cleodendrum infortunatum. J Pharm Sci 2005;5(1-2):63-6.

11. Sharma A, Shankar C, Tyagi L, Singh M, Rrao C. Herbal medicine for market potential in india: an overview. Acad J Plant Sci 2008;2:26-36.

12. Kapoor LD. Handbook of Ayurvedic Medicinal Plants.1st ed. New Delhi: CRC Press; 2001. p. 124-5.

13. Gupta S, Gupta R. Detection and quantification of quercetin in roots, leaves and flowers of Clerodendrum infortunatum $\mathrm{L}$. Asian Pac J Trop Dis. 2012; 2 (2), 940-943.

14. Litchfield,J.R. and F. Welcoxon, 1949. A simplified method of evaluating dose effect experiments. Journal of Pharmacolology Experimental Therapeutics, 96: 99-133.

15. Hollander D, Tarnawski A, Gergely H, Zipser RD. Sucralfate protection of the gastric mucosa against alcohol-induced injury: a prostaglandin-mediated process? Scandinavian Journal of Gastroenterology. 1984,19 (Suppl. 101), 97-102.

16. Gupta MB, Nath R, Gupta GP, Bhargava KP. A study of the antiulcer activity of diazepam and other tranquillosedatives in albino rats. Clinical and Experimental Pharmacology. 1985; 12: 61-63.

17. Goel RK, Maiti RN. Gastric ulcer protective effect of Tamrabhasma, an Indian Ayurvedic preparation of copper and plantain banana. Proceedings of First International Symposium on natural drugs and the digestive tract, Naples, Italy. 1992; pp. 73-76.

18. Sanyal AK, Debnath PK, Bhattacharya SK, Gode KD. The effect of cyproheptadine on gastric activity, an experimental study. In: Pfeiffer, C.J. (Ed.), Peptic Ulcer. Munksgaard, Copenhagen, 1971; 312- 318.

19. Corne SJ, Morrissey SM, Woods RJ. 1974. A method for the quantitative estimation of gastric barrier mucus. Proc. Physiol. Soc. 242:116-117.

20. Debnath PK, Gode KD, Das GD, Sanyal AK. Effect of propranolol on gastric secretion in albino rats. British Journal of Pharmacology. 1974; 51:213-216.

21. Lowry $\mathrm{OH}$, Rosenborough NJ, Farr AL, Randal RJ. Protein measurement with Folin phenol reagent. Journal of Biological Chemistry. 1951; 193:265-275.

22. Sanyal AK, Mitra PK, Goel RK. A modified method to estimate dissolved mucosubstances in gastric juice. Indian Journal of Experimental Biology. 1983; 21:78-80.

23. Mukhopadhyay K, Bhattacharya D, Chakrabarti A, Goel RK, Sanyal AK. Effect of banana powder (Musa sapientum var. paradisiaca) on gastric mucosal shedding. Journal of Ethnopharmacology. 1987; 21:11-19.

24. Goel RK, Maiti RN, Mukhopadhyaya K. Effect of Tamrabhasma, an indigenous preparation of copper, on rat gastric mucosal resistance. Indian Journal of Experimental Biology. 1994; 32:559-561.

25. Goel RK, Gupta S, Shankar R, Sanyal AK. Antiulcerogenic effect of Banana powder (Musa sapientum var. paradisiaca) and its effect on mucosal resistance. Journal of Ethnopharmacology. 1986; 18, 33-44.
26. Das D, Banerjee RF. Effect of stress on the antioxidant enzymes and gastric ulceration. Molecular and Cellular Biochemistry. 1993; $125: 115-125$

27. Goel RK, Sairam K, Rao ChV, Raman A. Role of gastric antioxidant and anti-Helicobacter pylori activities in the antiulcerogenic activity of plantain banana (Musa sapientum var. paradisiaca). Indian Journal of Experimental Biology. 2001; 39:719-722.

28. Ohkawa H, Ohishi N, Yagi K. Assay for lipid peroxides in animal tissues by thiobarbituric acid reaction. Analytical Biochemistry. 1979; 95:351-358.

29. Kakkar P, Das B, Viswanathan PN. A modified spectrophotometric assay of superoxide dismutase. Indian Journal of Biochemistry and Biophysics. 1984; 21:130-132.

30. Beers RF, Sizer IW. A spectrophotometric method for measuring the breakdown of hydrogen peroxide by catalase. Journal of Biological Chemistry. 1952; 195:133-140.

31. Oates PJ, Hakkinen JP. Studies on the mechanism of ethanolinduced gastric damage in rats. Gastroenterology. 1988; 94:10-21.

32. Mizui T, Sato H, Hirose F, Doteuchi M. Effect of antiperoxidative drugs on gastric damage induced by ethanol in rats. Life Sciences. 1987; 41:755-763.

33. Peskar BM, Lange K, Hoppe U, Peskar BA. Ethanol stimulates formation of leukotriene $\mathrm{C} 4$ in rat gastric mucosa. Prostaglandins. 1986; 31:283-293.

34. Miller TA, Henagan JM. Indomethacin decreases resistance of gastric barrier to disruption by alcohol. Digestive Diseases Science. 1984; 29:141- 149.

35. Goel RK, Bhattacharya SK. Gastroduodenal mucosal defense and mucosal protective agents. Indian Journal of Experimental Biology. 1991; 29:701- 714.

36. Sairam K, Rao ChV, Dora Babu M, Agrawal VK, Goel RK. Antiulcerogenic activity of methanolic extract of Emblica officinalis. Journal of Ethnopharmacology. 2002; 82(1): 1-9.

37. Rege NN, Thatte UN, Dahanukar SA. Adaptogenic properties of six rasayana herbs used in Ayurvedic medicine. Phytotherapy Research. 1999; 13: 275- 291.

38. Ahmad I, Mehmood Z, Mohammad F. Screening of some Indian medicinal plants for their antimicrobial properties. Journal of Ethnopharmacology. 1998; 62:183-193.

39. Williams SE, Turnberg LA. Retardation of acid diffusion by pig gastric mucus: a potential role in mucosal protection. Gastroenterology. 1980; 79:299- 304.

40. Miller TA. Mechanisms of stress-related mucosal damage. American Journal of Medicine. 1987; 83:8-14.

41. Okabe S, Pfeiffer CJ. Chronicity of acetic acid ulcer in the rat stomach. Digestive Diseases. 1972; 7:619- 629.

42. Cho $\mathrm{CH}$, Ogle $\mathrm{CW}$, Dai $\mathrm{S}$. Acute gastric ulcer formation in response to electrical vagal stimulation in rats. European Journal of Pharmacology. 1976; 35;215-219.

43. Cho $\mathrm{CH}$, Ogle $\mathrm{CW}$. Cholinergic-mediated gastric mast cell degranulation with subsequent histamine $\mathrm{H} 1$ and $\mathrm{H} 2$-receptor activation in stress ulceration in rats. European Journal of Pharmacology. 1979; 55:23-33.

44. Hase T, Moss BJ. Microvascular changes of gastric mucosa in development of stress ulcers in rats. Gastroenterology. 1973; 65:224-322.

45. Rao ChV, Maiti RN, Goel RK. Effect of mild irritant on gastric mucosal offensive and defensive factors. Indian Journal of Physiology and Pharmacology. 1999; 44;185-191.

46. Cochran T, Stefanko J, Moore C, Saik R. Dimethylsulfoxide protection against gastric stress ulceration. Current Surgery. 1983; 40:435- 437.

47. Fridovich I. Biological effects of super oxide radical. Archives of Biochemistry and Biophysics. 1986; 247:1-11.

48. Das D, Bandyopadhyay D, Bhattacharya M, Banarjee RK. Hydroxyl radical is the major causative factor in stress-induced gastric ulceration. Free Radical Biology and Medicine. 1997; 23:8-18. 